\title{
Effect of Zinc on Some Grain Quality Parameters in Bread and Durum Wheat Cultivars
}

\author{
İlknur Akgun ${ }^{1, *}$, Ruziye Karaman ${ }^{1}$, Figen Eraslan $^{2}$, Muharrem Kaya $^{1}$ \\ ${ }^{1}$ Department of Field Crops, Faculty of Agriculture, Suleyman Demirel University, Turkey \\ ${ }^{2}$ Department of Soil Science and Plant, Faculty of Agriculture, Suleyman Demirel University, Turkey
}

Copyright $\mathrm{C} 2016$ by authors, all rights reserved. Authors agree that this article remains permanently open access under the terms of the Creative Commons Attribution License 4.0 International License

\begin{abstract}
This research was conducted in Isparta, Turkey ecological condition to investigate the effects of different zinc application doses on some quality parameters of bread (Gün-91, Altay-2000) and durum (Kizıltan-91, Kunduru-1149) wheat cultivars. The experiment was set up with three replications according to the randomized complete block design with a split-plot design. The cultivars took place in the main plots whereas the zinc application doses $(0$, 9, 18, 27 and $36 \mathrm{~kg} \mathrm{ha}^{-1} \mathrm{Zn}$ ) were in the sub-plots. Phosphorus and nitrogen fertilizers providing $40 \mathrm{~kg} \mathrm{ha}^{-1}$ of $\mathrm{P}_{2} \mathrm{O}_{5}$ and $80 \mathrm{~kg} \mathrm{ha}^{-1}$ of $\mathrm{N}$ were applied to the plots. According to the result of variance analysis, different zinc application in wheat cultivars had significant effect on the grain quality parameters. But zinc fertilization had no effect on test weight. The effect of $\mathrm{Zn}$ treatment found statistically important on sedimentation and wet gluten content of flour, $\mathrm{Zn}, \mathrm{P}$ and crude protein contents of bran and flour. In all cultivars, $\mathrm{Zn}$ application increased sedimentation, wet gluten content, protein, $\mathrm{Zn}$ content and $\mathrm{P}$ content in bran. However, the $\mathrm{Zn}$ application decreased the amount of $P$ in flour. Also, protein, $\mathrm{Zn}$ and $\mathrm{P}$ contents were higher in the bran than in the flour. In the research results, it was found that $\mathrm{Zn}$ application had a positive effect on quality parameters, but high $\mathrm{Zn}$ doses affected both grain yield and quality parameters negatively.
\end{abstract}

Keywords Wheat, Zinc, Test Weight, Flour, Bran, Quality

\section{Introduction}

Bread and other cereal products are the main staples for Turkish people. Approximately $50 \%$ of the daily energy need is supplied from wheat products [1]. In Turkey, the average wheat yield increased approximately up to $3000 \mathrm{~kg}$ $\mathrm{ha}^{-1}$ in recent years. Approximately half $(49.8 \%)$ of the agricultural land in Turkey has zinc deficiency and this is more prominent in Central Anatolia region [2]. It is considered that $\mathrm{Zn}$ content of the cultivated plants normally varies between 20 and $100 \mathrm{mg} \mathrm{kg}^{-1}$ on dry matter basis and $\mathrm{Zn}$ critical level is $10-15 \mathrm{mg} \mathrm{kg}^{-1}$ in many types of grain [3]. In a study conducted to determine the zinc content of the soil, available zinc content in Isparta province soils was found as $0.10 \mathrm{ppm}$ [4]. On the other hand, soil containing less than 0.5 $\mathrm{mg} \mathrm{kg}{ }^{-1}$ zinc are considered as weak soils [5]. Considering these data, it can be said that Isparta and the surrounding area has lack of zinc in the soil.

The effect of environmental conditions on grain quality mentioned in previous works focused largely on the effects of macronutrients [6]. On the other hand, it was demonstrated that the micronutrients have effect on grain quality shown by flours derived from $\mathrm{Cu}$ and $\mathrm{Zn}$ deficient wheat produced dough [7]. Increase in available $\mathrm{Zn}$ can increase grain protein concentration [8], which may preferentially accumulate in gluten. Starks and Johnson [9] indicated that $\mathrm{Zn}$ is associated with the seed storage proteins of wheat. Gluten is the major component of flour protein that determines processing quality.

The purpose of this study was to examine the effects of the zinc fertilization in different wheat cultivars on test weight, sedimentation value and wet gluten amount in flour; (ii) on protein, zinc and phosphorus contents in different parts (the flour and bran) of grain.

\section{Materials and Methods}

The field experiments were carried out at the Experimental Area of the Faculty of Agriculture, Süleyman Demirel University, Isparta ( $37^{\circ} 45^{\prime} \mathrm{N} ; 30^{\circ} 33^{\prime} \mathrm{E}$; and 1050 $\mathrm{m})$, Turkey, under rainfed conditions. In the field experiment, two bread wheat cultivars (Gün-91 and Altay-2000) and two durum wheat cultivars (Kizıltan-91 and Kunduru-1149) were used. The experiment included five zinc application rates $(0$, 9, 18, 27 and $36 \mathrm{~kg} \mathrm{ha}^{-1} \mathrm{Zn}$ ). The study was carried out on 4 wheat cultivars on split-plot design in a randomized complete block with 3 replications. The varieties were placed on main plots whereas zinc application rates were placed on sub-plots. Sowing was done by plot sowing 
machine providing 500 seeds per $\mathrm{m}^{2}$. The basal fertilizer applications were $40 \mathrm{~kg} \mathrm{ha}^{-1} \mathrm{P}_{2} \mathrm{O}_{5}$ and $80 \mathrm{~kg} \mathrm{ha}^{-1} \mathrm{~N}$ as triple superphosphate and ammonium sulphate, respectively. All of the phosphorus fertilizers were applied with sowing. Nitrogen fertilization was applied in two equal doses, during sowing in autumn (October) and in early spring (March) when plants were at the tillering stage. Zinc sulphate was used as zinc fertilizer and was applied with sowing. Plot sizes were $9.6 \mathrm{~m}^{2}(1.2 \mathrm{~m} \mathrm{x} 8 \mathrm{~m})$, with 6 rows and a row spacing of $20 \mathrm{~cm}$. The wheat samples obtained from each plot after harvest in the research was stored at $4-10^{\circ} \mathrm{C}$. The wheat grains were ground in 2013. It was separated into bran and flour. Milled flour samples were sieved $212 \mu$ diameter and the bran and flour were separated again. The bran on the sieve was mixed the former bran. In the research, sedimentation and wet gluten content of flour samples in $\mathrm{Zn}$ application were determined according to Özkaya and Özkaya [10]. In bran and flour samples, concentrations of Zn were determined by atomic absorption spectrometry after ashing samples at $550^{\circ} \mathrm{C}$ and dissolving ash in $3.3 \% \mathrm{HC} 1$ [2], $\mathrm{P}$ by the vanadate-molybdate colorimetric method [11] and the protein content was calculated by multiplying the Kjeldahl $\mathrm{N}$ by 6.25 .

The soil of the research areas had a low water-holding capacity, was alkaline $(\mathrm{pH} 7.9-8.3)$ and Lime (25.5-30\% $\mathrm{CaCO}_{3}$ ), and contained a low amount of organic matter (1.15-1.34 \%). The $\mathrm{P}_{2} \mathrm{O}_{5}, \mathrm{~N}$ and $\mathrm{Zn}$ contents were 192-197 $\mathrm{mg} \mathrm{kg}{ }^{-1}, 0.4-0.17 \%$ and $0.52-0.79 \mathrm{ppm}$, respectively.

The weather conditions during the two years were different [12]. The long-term average temperature from September to June was $9.5^{\circ} \mathrm{C}$. Precipitation was $453.4 \mathrm{~mm}$ for the same period. The growing seasons (from October to June) in 2009-2010 and 2010-2011 had average temperatures of 10.7 and $9.8^{\circ} \mathrm{C}$, total precipitation of 620.2 and $459.3 \mathrm{~mm}$ respectively. During the 2010-2011 growing season, there was quite a lot of rainfall during germination. In contrast, the 2009-2010 seasons were warmer during the seed filling stage.

\subsection{Statistical Analysis}

Averages of two years were pooled and according to the average of two-year results, statistical analysis was carried out using MSTAT-c statistical package program. The calculated mean values were compared using Duncan's multiple range test.

\section{Results}

\subsection{Test Weight}

The effect of the cultivar and dose of zinc applications was not significant. According to the average of two-year results, test weight (weight of 100 liter) changed among doses $80.65-81.86 \mathrm{~kg}$, cultivars $80.91-81.72 \mathrm{~kg}$ (Table 1). On the other hand, variety $\mathrm{x}$ dose interaction was significant. The effect of $\mathrm{Zn}$ applications on varieties was different and comparing to control $\left(0 \mathrm{~kg} \mathrm{Zn} \mathrm{ha}^{-1}\right)$ the increase ratio in test weight in Altay-2000 was significant, whereas test weight in other wheat cultivars was not significant. The maximum test weight in Altay-2000 was obtained from $36 \mathrm{~kg} \mathrm{ha}^{-1}$ zinc application $(82.85 \mathrm{~kg})$, followed by $27 \mathrm{~kg} \mathrm{ha}^{-1}$ zinc application. But the test weight in 18, 27 and $36 \mathrm{~kg} \mathrm{ha}^{-1}$ zinc applications was similar to each other and was not significant. This showed that sensitivity of varieties to $\mathrm{Zn}$ deficiency was different.

\subsection{Wet Gluten Content}

Both cultivar and $\mathrm{Zn}$ applications significantly affected wet gluten content in bread and durum wheat cultivars $(\mathrm{P} \leq 0.01$; Table 2). As general average, content of wet gluten of durum wheat was more than those in bread wheat. The different response of varieties to $\mathrm{Zn}$ applications showed variety $\mathrm{x} \mathrm{Zn}$ interaction.

As two-year average, the highest content of wet gluten was in Kunduru-1149 (31.45\%), whereas the lowest was in Gün-91 (27.06\%) and compared to others Kunduru had higher value than others (Table 2). Wet gluten content of Gün-91 and Altay-2000 was similar to each other. Different $\mathrm{Zn}$ applications in wheat cultivars had a positive effect on amount of wet gluten. But in the experiment the amount of wet gluten had variations depending on the genotypes. While the lowest amount of wet gluten in all cultivars was obtained from control, the highest values was found in Altay- 2000 (28.88\%), Gün-91 (30.43\%) and Kunduru-1149 (37.33\%) varieties in $36 \mathrm{~kg} \mathrm{ha}^{-1} \mathrm{Zn}$ application, and Kizıltan-91 $(31.70 \%)$ variety had highest wet gluten at $27 \mathrm{~kg} \mathrm{ha}^{-1} \mathrm{Zn}$ application.

Table 1. The effect of zinc fertilization on the test weight $(\mathrm{kg})$ according to the average two-year results in bread and durum wheat varieties.

\begin{tabular}{|c|c|c|c|c|c|c|}
\hline \multirow{2}{*}{ Cultivar } & \multicolumn{5}{|c|}{ Zinc Application $\left(\mathrm{kg} \mathrm{ha}^{-1}\right)$} & \multirow{2}{*}{ Average } \\
\hline & 0 & 9 & 18 & 27 & 36 & \\
\hline Altay-2000 & $79.32 b^{l}$ & $79.82 b$ & $81.61 a b$ & $81.84 a b$ & $82.85 a$ & 81.09 \\
\hline Gün-91 & 79.86 & 80.47 & 81.47 & 81.90 & 80.83 & 80.91 \\
\hline Kizıltan-91 & 83.09 & 81.31 & 82.00 & 81.09 & 81.15 & 81.72 \\
\hline Kunduru-1149 & 80.32 & 81.11 & 82.37 & 82.01 & 79.67 & 81.10 \\
\hline Average & 80.65 & 80.68 & 81.86 & 81.71 & 81.12 & \\
\hline \multicolumn{7}{|c|}{ Variety(a),2.452 ns ; Zn Dose (b),1.124 ns; } \\
\hline
\end{tabular}

${ }^{1}$ Means with different superscript in the same row differ $(\mathrm{P}<0.05)$; ns: Non significant 
Table 2. The effect of zinc fertilization on content of wet gluten (\%) according to the average two-year results in bread and durum wheat varieties

\begin{tabular}{|c|c|c|c|c|c|c|}
\hline \multirow{2}{*}{ Cultivar } & \multicolumn{5}{|c|}{ Zinc Application $\left(\mathrm{kg} \mathrm{ha}^{-1}\right)$} & \multirow{2}{*}{ Average } \\
\hline & $\mathbf{0}$ & 9 & 18 & 27 & 36 & \\
\hline Altay-2000 & $26.28 b^{1}$ & $26.08 b$ & $26.34 b$ & $28.34 \mathrm{a}$ & $28.88 \mathrm{a}$ & 27.18 \\
\hline Gün-91 & $22.53 \mathrm{~d}$ & $26.08 \mathrm{c}$ & $27.87 \mathrm{~b}$ & $28.41 b$ & $30.43 a$ & 27.06 \\
\hline Kizıltan-91 & $27.58 \mathrm{c}$ & $29.50 \mathrm{~b}$ & $31.32 \mathrm{a}$ & $31.70 \mathrm{a}$ & $29.59 b$ & 29.94 \\
\hline Kunduru-1149 & $23.76 \mathrm{~d}$ & $30.95 \mathrm{c}$ & $32.75 b$ & $32.47 \mathrm{~b}$ & $37.33 a$ & 31.45 \\
\hline Average & 25.04 & 28.72 & 29.57 & 29.67 & 31.56 & \\
\hline \multicolumn{7}{|c|}{ Variety(a),182.829**; Zn Dose (b),160.135**; AxB, $33.359 * * ; C V(a)=2.46 \% ; C V(b)=2.63 \%$} \\
\hline
\end{tabular}

${ }^{1}$ Means with different superscript in the same row differ $(\mathrm{P}<0.01)$; **: significant at $1 \%$ levels of probability

\subsection{Sedimentation}

Genotypes, $\mathrm{Zn}$ applications and their interactions on sedimentation values were significant ( $\mathrm{P} \leq 0.01$; Table 3$)$. As general average, sedimentation values of bread wheat cultivars (Altay-2000, $26.00 \mathrm{ml}$; Gün-91, $29.80 \mathrm{ml}$ ) were more than those in durum wheat varieties (Kiziltan-91, $16.75 \mathrm{ml}$; Kunduru-1149, $15.15 \mathrm{ml}$ ). The highest values of sedimentation (except Kiziltan-91) were found at highest $\mathrm{Zn}$ application dose $\left(36 \mathrm{~kg} \mathrm{ha}^{-1}\right)$. The lowest values were found in control.

Table 3. The effect of zinc fertilization on sedimentation ( $\mathrm{ml}$ ) according to the average two-year results in bread and durum wheat varieties

\begin{tabular}{|c|c|c|c|c|c|c|}
\hline \multirow{2}{*}{ Cultivar } & \multicolumn{5}{|c|}{ Zinc Application $\left(\mathrm{kg} \mathrm{ha}^{-1}\right)$} & \multirow{2}{*}{ Average } \\
\hline & $\mathbf{0}$ & 9 & 18 & 27 & 36 & \\
\hline Altay-2000 & $23.50 \mathrm{c}^{1}$ & $24.75 b$ & $25.25 b$ & $25.50 \mathrm{~b}$ & $31.00 \mathrm{a}$ & 26.00 \\
\hline Gün-91 & $28.50 \mathrm{~b}$ & $29.25 b$ & $28.50 \mathrm{~b}$ & $29.00 \mathrm{~b}$ & $33.75 \mathrm{a}$ & 29.80 \\
\hline Kızıltan-91 & $15.50 \mathrm{c}$ & $16.50 \mathrm{~b}$ & $18.00 \mathrm{a}$ & $16.25 b c$ & $17.50 \mathrm{a}$ & 16.75 \\
\hline Kunduru-1149 & $14.00 \mathrm{c}$ & $14.25 \mathrm{c}$ & $16.00 \mathrm{ab}$ & $15.25 \mathrm{~b}$ & $16.25 \mathrm{a}$ & 15.15 \\
\hline Average & 20.38 & 21.63 & 22.00 & 21.50 & 24.13 & \\
\hline
\end{tabular}

${ }^{1}$ Means with different superscript in the same row $\operatorname{differ}(\mathrm{P}<0.01)$; **: significant at $1 \%$ levels of probability

\subsection{Crude Protein Content}

Zinc applications increased crude protein content in both bran and flour significantly $(\mathrm{P} \leq 0.01)$. Also it was found that crude protein percent was lower in flour than in bran in all varieties (Table 4).

Table 4. The effect of zinc fertilization on protein content in bran and flour according to the average two-year results in bread and durum wheat varieties

\begin{tabular}{|c|c|c|c|c|c|c|c|c|}
\hline \multirow{2}{*}{$\begin{array}{c}\text { Zinc doses } \\
\left(\mathbf{k g ~ h a}^{-1}\right)\end{array}$} & \multicolumn{2}{|c|}{$\begin{array}{c}\text { Altay-2000 } \\
\text { Protein \% }\end{array}$} & \multicolumn{2}{c|}{$\begin{array}{c}\text { Gün-91 } \\
\text { Protein \% }\end{array}$} & \multicolumn{2}{c|}{$\begin{array}{c}\text { Kiziltan-91 } \\
\text { Protein \% }\end{array}$} & \multicolumn{2}{c|}{$\begin{array}{c}\text { Kunduru-1149 } \\
\text { Protein \% }\end{array}$} \\
\cline { 2 - 9 } & Bran & Flour & Bran & Flour & Bran & Flour & Bran & Flour \\
\hline 0 & $12.17 \mathrm{c}^{1}$ & $9.63 \mathrm{c}$ & $12.49 \mathrm{c}$ & $10.02 \mathrm{c}$ & $12.56 \mathrm{c}$ & $8.10 \mathrm{c}$ & $13.20 \mathrm{c}$ & $9.39 \mathrm{c}$ \\
9 & $14.13 \mathrm{a}$ & $10.39 \mathrm{ab}$ & $14.45 \mathrm{a}$ & $11.48 \mathrm{ab}$ & $13.60 \mathrm{ab}$ & $10.89 \mathrm{a}$ & $15.22 \mathrm{a}$ & $11.96 \mathrm{a}$ \\
18 & $13.09 \mathrm{~b}$ & $10.50 \mathrm{a}$ & $14.21 \mathrm{a}$ & $11.62 \mathrm{a}$ & $13.80 \mathrm{a}$ & $10.46 \mathrm{a}$ & $14.55 \mathrm{~b}$ & $11.70 \mathrm{a}$ \\
27 & $12.42 \mathrm{c}$ & $9.89 \mathrm{bc}$ & $13.16 \mathrm{~b}$ & $10.96 \mathrm{~b}$ & $13.58 \mathrm{ab}$ & $8.90 \mathrm{~b}$ & $12.74 \mathrm{~d}$ & $10.04 \mathrm{~b}$ \\
36 & $12.26 \mathrm{c}$ & $9.71 \mathrm{c}$ & $13.02 \mathrm{~b}$ & $10.16 \mathrm{c}$ & $13.24 \mathrm{~b}$ & $8.89 \mathrm{~b}$ & $12.41 \mathrm{~d}$ & $9.70 \mathrm{bc}$ \\
\hline Average & $\mathbf{1 2 . 8 1}$ & $\mathbf{1 0 . 0 3}$ & $\mathbf{1 3 . 4 7}$ & $\mathbf{1 0 . 8 5}$ & $\mathbf{1 3 . 3 5}$ & $\mathbf{9 . 4 5}$ & $\mathbf{1 3 . 6 2}$ & $\mathbf{1 0 . 5 6}$ \\
\hline \multicolumn{6}{c}{ Bran: Variety(a),23.255** ; Zn Dose (b), $97,840 * * ; \mathrm{AxB}, 9.135 * * ; \mathrm{CV}(\mathrm{a})=2.44 \% ; \mathrm{CV}(\mathrm{b})=2.35 \%$} \\
\hline
\end{tabular}

${ }^{1}$ Means with different superscript in the same column differ $(\mathrm{P}<0.01)$; **: significant at $1 \%$ levels of probability

Protein content increased up to $18 \mathrm{~kg} \mathrm{ha}^{-1}$ zinc application after which applying higher Zinc doses significantly reduced protein content in the all varieties. The lowest values of protein content in flour and bran were found in control. In this study, it was found that Gün-91 and Kunduru-1149 varieties had better zinc use efficiency and nutrients in soil are better utilized. 


\subsection{Zinc (Zn) Concentrations}

Zinc applications affected $\mathrm{Zn}$ concentrations of cultivars. Cultivar, $\mathrm{Zn}$ treatments and their interactions on $\mathrm{Zn}$ concentrations of bran and flour were significant $(\mathrm{P} \leq 0.01$; Table 5), while effect of year was not significant. According to the two years means, $\mathrm{Zn}$ concentrations significantly increased both in bran and flour of cultivars. The lowest $\mathrm{Zn}$ concentrations of bran and flour were obtained from control group. Generally, Zn concentrations of grain were increased by increasing $\mathrm{Zn}$ applications (Table 5).

Although $\mathrm{Zn}$ concentration of bran was higher than flour, $\mathrm{Zn}$ applications relatively increased $\mathrm{Zn}$ concentration in flour more than those in bran (the increase rates in flour compared to control $\left(0 \mathrm{~kg} \mathrm{ha}^{-1}\right)$ were $82,61,85$ and $89 \%$ for Altay-2000, Gün-91, Kizıltan-91, Kunduru-1149, respectively). The average $\mathrm{Zn}$ concentrations of bran of bread wheat (Altay-2000, $70.8 \mathrm{mg} \mathrm{kg}^{-1}$; Gün-91, $72.9 \mathrm{mg}$ $\mathrm{kg}^{-1}$ ) were higher than durum wheat cultivars (K1z1ltan-91 $36.4 \mathrm{mg} \mathrm{kg}^{-1}$; Kunduru-1149, 40.1 $\mathrm{mg} \mathrm{kg}^{-1}$ ).

\subsection{Phosphorus (P) Concentrations}

Zinc treatments, cultivars and their interaction significantly affected the $\mathrm{P}$ concentrations of bran and flour $(\mathrm{P} \leq 0.01$; Table 6). Zinc treatments decreased the $\mathrm{P}$ concentration in flour but increased in bran for all the wheat cultivars. The bran $\mathrm{P}$ concentration of bread wheat (Altay-2000, 0.3\%; Gün-91, 0.4\%) was higher than the flour $\mathrm{P}$ concentration of durum wheat (K1z1ltan-91, 0.18\%; Kunduru-1149, 0.19\%). The P concentration of bran of bread wheat increased up to $27 \mathrm{~kg} \mathrm{ha}^{-1}$ of $\mathrm{Zn}$ application. The lowest $\mathrm{P}$ concentration of bran of bread wheat was obtained from control group. The $\mathrm{P}$ concentration of bran of durum wheat increased up to $9 \mathrm{~kg} \mathrm{ha}^{-1}$ of $\mathrm{Zn}$ application (K1ziltan-91, $0.42 \%$; Kunduru-1149, 0.45\%), however difference between control and $9 \mathrm{~kg} \mathrm{ha}{ }^{-1}$ was not significant. The $P$ concentrations of both bran and flour of all cultivars significantly decreased at $36 \mathrm{~kg} \mathrm{ha}^{-1} \mathrm{Zn}$ treatment (Table 6).

Table 5. The effect of zinc fertilization on zinc ( $\mathrm{Zn})$ content according to the average two-year results in bread and durum wheat varieties

\begin{tabular}{|c|c|c|c|c|c|c|c|c|}
\hline \multirow{2}{*}{$\begin{array}{l}\text { Zn doses } \\
\left(\mathrm{kg} \mathrm{ha}^{-1}\right)\end{array}$} & \multicolumn{2}{|c|}{$\begin{array}{l}\text { Altay-2000 } \\
\text { Zn mg kg }^{-1}\end{array}$} & \multicolumn{2}{|c|}{$\begin{array}{c}\text { Gün-91 } \\
\text { Zn mg kg-1 }^{-1}\end{array}$} & \multicolumn{2}{|c|}{$\begin{array}{l}\text { Kiziltan-91 } \\
\text { Zn mg kg }^{-1} \\
\end{array}$} & \multicolumn{2}{|c|}{$\begin{array}{c}\text { Kunduru-1149 } \\
\mathrm{Zn} \mathrm{mg} \mathrm{kg}^{-1} \\
\end{array}$} \\
\hline & Bran & Flour & Bran & Flour & Bran & Flour & Bran & Flour \\
\hline 0 & $66.75 \mathrm{e}^{1}$ & $11.61 \mathrm{~d}$ & $60.71 \mathrm{e}$ & $12.95 \mathrm{e}$ & $32.19 \mathrm{~d}$ & $11.92 \mathrm{e}$ & $38.25 \mathrm{e}$ & $12.49 \mathrm{~d}$ \\
\hline 9 & $70.32 c$ & $15.94 \mathrm{c}$ & $72.67 \mathrm{c}$ & $16.00 \mathrm{~d}$ & $36.52 \mathrm{c}$ & $18.96 \mathrm{c}$ & $40.70 \mathrm{c}$ & $21.61 \mathrm{~b}$ \\
\hline 18 & $72.03 b$ & $17.24 b$ & $78.16 \mathrm{~b}$ & $18.55 \mathrm{~b}$ & $37.79 b$ & $22.17 \mathrm{a}$ & $42.55 b$ & $20.90 \mathrm{c}$ \\
\hline 27 & 76.91a & $21.12 \mathrm{a}$ & $82.54 \mathrm{a}$ & $20.88 \mathrm{a}$ & $40.93 \mathrm{a}$ & $19.60 \mathrm{~b}$ & $43.60 \mathrm{a}$ & $23.58 \mathrm{a}$ \\
\hline 36 & $67.80 \mathrm{~d}$ & $12.10 \mathrm{~d}$ & $70.17 \mathrm{~d}$ & $16.67 \mathrm{c}$ & $37.30 \mathrm{bc}$ & $14.58 \mathrm{~d}$ & $39.46 \mathrm{~d}$ & $21.50 \mathrm{~b}$ \\
\hline Ave. & 70.76 & 15.60 & 72.85 & 17.01 & 36.94 & 17.44 & 40.91 & 20.02 \\
\hline \multicolumn{9}{|c|}{ Bran: Variety(a),8560,099**; Zn Dose (b), 719,390 **;AxB, 82,158**;CV(a)=1,66\%; CV(b) = 1,16\% } \\
\hline \multicolumn{9}{|c|}{ Flour:Variety(a),364,335** Zn Dose (b), 1087,818**; AxB, 80,558**; CV(a) =2,92\%; CV(b) =2,14\% } \\
\hline
\end{tabular}

${ }^{1}$ Means with different superscript in the same column differ $(\mathrm{P}<0.05)$; **: significant at $1 \%$ levels of probability

Table 6. The effect of zinc fertilization on phosphorus $(\mathrm{P})$ content in bran and flour according to the average two-year results in bread and durum wheat varieties

\begin{tabular}{|c|c|c|c|c|c|c|c|c|}
\hline \multirow{2}{*}{$\begin{array}{c}\text { Zinc } \\
\text { doses(kg } \\
\left.\text { ha }^{-1}\right)\end{array}$} & \multicolumn{2}{|c|}{$\begin{array}{c}\text { Altay-2000 } \\
\text { P (\%) }\end{array}$} & \multicolumn{2}{|c|}{$\begin{array}{c}\text { Gün-91 } \\
\text { P (\%) }\end{array}$} & \multicolumn{2}{|c|}{$\begin{array}{c}\text { Kizıltan-91 } \\
\text { P (\%) }\end{array}$} & \multicolumn{2}{|c|}{$\begin{array}{c}\text { Kunduru-1149 } \\
\text { P (\%) }\end{array}$} \\
\hline & Bran & Flour & Bran & Flour & Bran & Flour & Bran & Flour \\
\hline 0 & $0.458 \mathrm{c}^{1}$ & $0.165 \mathrm{a}$ & $0.510 \mathrm{c}$ & $0.163 \mathrm{a}$ & $0.395 \mathrm{ab}$ & $0.198 \mathrm{a}$ & $0.430 \mathrm{ab}$ & $0.210 \mathrm{a}$ \\
\hline 9 & $0.555 \mathrm{~b}$ & $0.156 \mathrm{ab}$ & $0.553 b$ & $0.163 \mathrm{a}$ & $0.415 \mathrm{a}$ & $0.188 \mathrm{ab}$ & $0.453 \mathrm{a}$ & $0.205 \mathrm{a}$ \\
\hline 18 & $0.553 b$ & $0.153 \mathrm{ab}$ & $0.570 \mathrm{~b}$ & $0.158 \mathrm{ab}$ & $0.398 \mathrm{ab}$ & $0.183 b c$ & $0.440 \mathrm{a}$ & $0.170 \mathrm{~b}$ \\
\hline 27 & $0.605 a$ & $0150 \mathrm{~b}$ & $0.648 \mathrm{a}$ & $0.148 b$ & $0.358 \mathrm{bc}$ & $0.183 b c$ & $0.433 \mathrm{a}$ & $0.180 \mathrm{~b}$ \\
\hline 36 & $0.485 \mathrm{c}$ & $0.125 \mathrm{c}$ & $0.435 d$ & $0.118 \mathrm{c}$ & $0.338 \mathrm{c}$ & $0.170 \mathrm{c}$ & $0.390 \mathrm{~b}$ & $0.180 \mathrm{~b}$ \\
\hline Ave. & 0.531 & 0.150 & 0.543 & 0.149 & 0.380 & 0.184 & 0.428 & 0.189 \\
\hline \multicolumn{9}{|c|}{ Bran:Variety(a), 159,220**; Zn Dose (b), 30,363**; AxB, 8,619**;CV(a)=4,95\%; CV(b) $=5,16 \%$} \\
\hline
\end{tabular}

${ }^{1}$ Means with different superscript in the same column differ $(\mathrm{P}<0.05), * *$ : significant at $1 \%$ levels of probability 


\section{Discussion}

Test weight, on the quality of wheat is one of the traits that are effective, and it is required to be above $80 \mathrm{~kg}$ [13]. Test weight can be affected by factors such as; variety, environmental conditions, cultural practices, pests and diseases [14].In this study, the effect of the varieties and dose of zinc applications was not significant. But test weight of durum wheat, compared to bread wheat was higher and zinc application had significant increase on particularly bread wheat varieties. Test weight was around $79 \mathrm{~kg}$ in control, and it increased up to $80 \mathrm{~kg}$ with zinc applications. In this study, sensitivity of varieties to $\mathrm{Zn}$ deficiency was different. The response of varieties to $\mathrm{Zn}$ deficiency could be related with the ability of taking $\mathrm{Zn}$ from the soil and using at different efficiency in plant tissues [15].On the other hand, it was reported that high $\mathrm{Zn}$ concentration reduced plant growth, seed number and seed weight [16].In our study, high doses of zinc application negatively affected the test weight, whereas this difference between control and $36 \mathrm{~kg} \mathrm{ha}^{-1}$ was not significant. Previous research showed similar results to our results indicating that $\mathrm{Zn}$ application had no significant effect on test weight [17].

Grain protein content and protein quality is the most important one of the traits in wheat. The amount and composition of endosperm storage protein has influence on the rheological properties of dough made from flour of bread wheat [7].It was shown that the environmental conditions, genotypic variation and cultural applications has effect to grain protein content $[7,18]$.In our research, variety and $\mathrm{Zn}$ applications significantly affected crude protein content. As general average, crude protein content of durum wheat was more than those in bread wheat.

In determining the bread quality, gluten quantity and sedimentation value are important. The reduction in dough strength is associated with a decrease in gluten content in flour and an increase in the gliadin:glutenin ratio [7].Mineral nutrition had a major role in determining grain quality. Most of previous works concentrated on the effects of macro elements. The effectiveness of microelement received little attention. In this study it was found that genetic properties and zinc application are effective on wet gluten content, sedimentation value, protein content. Similar results were obtained by different researchers [19, 20]. On the other hand, it was shown that variety was more effective on sedimentation value than environmental conditions [21].In this study, bread wheat sedimentation value was higher than durum wheat. This result showed that heredity has more effect than environment. Mineral analysis of the genotypes showed a large genetic variation for $\mathrm{Zn}, \mathrm{P}$ and protein concentrations under $\mathrm{Zn}$ application.

In another study, it was found that there is a positive relation between gluten and protein content [19],also zinc content and protein content [22] in wheat. Additionally, Peck et al. [7]showed that $\mathrm{Zn}$ nutrition can alter protein composition and effects of $\mathrm{Zn}$ may interact with grain filling temperatures. Increasing available $\mathrm{Zn}$ increased grain protein content by gluten accumulation [8].

In this study, protein, zinc and phosphorus contents were higher in bran than in flour. This data showed that most of zinc in seed accumulated in embryo and aleuron layer, but less of it was in endosperm. Öztürk et al. [23] reported that zinc content of wheat in embryo and aleuron layer was 150 $\mathrm{mg} \mathrm{kg}{ }^{-1}$ but $15 \mathrm{mg} \mathrm{kg}^{-1}$ in endosperm.

In this study, it was found that except phosphorus content in flour, zinc application positively affected other examined characters. Protein and zinc contents significantly decreased in control and high zinc application doses. Otherwise, phosphorus content in flour in all varieties decreased by zinc application and the highest phosphorus content was in control group. It has been reported that phosphorus content in seed decreased in different plant varieties depending on zinc application $[24,25]$

The nutritive quality and content of wheat grain is very important because daily calorie needs of our country are mostly supplied from the bread. In developing countries, it has been reported that daily $\mathrm{Zn}$ intake varies between 9-11 $\mathrm{mg}$ for an average person but this value is below than 15-20 $\mathrm{mg}$ which has been recommended for an adult [26].Microelement deficiency such as $\mathrm{Zn}$ negatively affects the human health [27]. Thus the production of cereals enriched with Zinc content is necessary.

\section{Conclusions}

According to the two-year results, $\mathrm{Zn}$ applications increased the grain yield and quality both of bread and durum wheat. For this reason, $\mathrm{Zn}$ applications should be recommended in $\mathrm{Zn}$ deficient fields to increase the yield and quality of wheat. This research indicated that the grain parts used in making bread are very important. Also, adding bran to flour at certain percentages would increase nutritional value of the bread.

\section{Acknowledgements}

We all thank to the workers and executives of Hediye Flour Factory who helped us mill the samples and conduct gluten and sedimentation analysis in this study.

\section{REFERENCES}

[1] Çakmak, I. 2008. Enrichment of cereal grains with zinc: agronomic or genetic biofortification? Plant Soil. 302, 1-17.

[2] Çakmak, I., Yilmaz, A., Kalayci, M., Ekiz, H., Torun, B., Erenoglu, B., Braun, H.J., 1996. Zinc deficiency as a critical problem in wheat production in Central Anatolia. Plant Soil. $180,165-172$.

[3] Kacar, B., Katkat, A.V., 1998. Plant Nutrition. Uludağ 
UniversityNo: 127, Bursa.

[4] Eyüpoğlu, F., Kurucu, N., Talaz, S., 1996. Türkiye Topraklarının Bitkiye Yarayışı Çinko Bakımından Genel Durumu. Köy Hizmetleri Genel Müdürlüğü Toprak ve Gübre Araştırma Enstitüsü, s:72, Ankara

[5] Lindsay, W. L., Norvell, W. A., 1978. Development of a DTPA soil test for $\mathrm{Zn}, \mathrm{Fe}, \mathrm{Mn}$ and $\mathrm{Cu}$. Soil Sci. Soc. Amer. Proc. 42, 421-428.

[6] SHewry, P.R., Napier, J.A., Tatham, A.S., 1995. Seed storage proteins, structures and biosynthesis. Plant Cell. 7, 945-956.

[7] Peck., A.W., Mcdonald,G.K., Graham R.D., 2008. Zinc nutrition influences the protein composition of flour in bread wheat (Triticum aestivum L.). Cereal Science. 47, 266-274.

[8] Hemantaranjan, A., Garg, O.K., 1988. Iron and zinc fertilization with reference to the grain quality of Triticum aestivum L. Plant Nutrition. 11, 1439-1450.

[9] Starks, T.L., Johnson, P.E., 1985. Techniques for intrinsically labeling wheat with $65 \mathrm{Zn}$. Journal of Agricultural and Food Chemistry. 33, 691-698.

[10] Özkaya, H., Özkaya, B., 2005. Analysis Methods of Cereal and Products. Food Technology Association Press., No: 31, Ankara.

[11] Kacar, B., Inal, A., 2008. Plant Analysis. Nobel No:1241, Ankara.

[12] Anonymous, 2009-2011. Climatic reports, Isparta Meteorological Station, Isparta.

[13] Yürür, N., 1994. Cool Climate Cereals. Uludağ University, No: 7. Bursa.

[14] Aydin, N., Bayramoglu, H.O., Mut Z., Özcan, H., 2005. Determination of yield and quality characters of bread wheat (Triticum aestivum L.) cultivars and lines under Black Sea region conditions of Turkey. Agricultural Sci. 11 (3), 257-262.

[15] Torun, B., Eker, S., Alkan, A., Isler, F., Çakmak, I., 1998. Sensitivity of different bread wheat cultivars to zinc deficiency. I. National Zinc Congress Proceeding Book, 12-16 Mayıs 1997, Eskişehir pp. 897-900.

[16] Khurana, N., Chatterjee, C., 2001. Influence of variable zinc on yield, oil content, and physiology of sunflower. Commun. Soil Science Plant Analysis. 32, 3023-3030.
[17] Kendal, E., 2008.Effect of Different Levels of Zinc Fertilization (ZnSO4) on Yield and Yield Components and Quality Traits of Some Durum Wheat Cultivars (Triticum Turgidum Var. Durum L.) in the South Eastern Anatolian Region Conditions. Department of Field Crops, Institute of Natural and Applied Sciences University of Cukurova, MSc Thesis, Adana.

[18] Panozzo, J.F., Eagles, H.A., 2000. Cultivar and environmental effects on quality characters in wheat. II. Protein. Australian Journal of Agricultural Research. 51, 629-636.

[19] GRausgruber, H., Oberfoster, M., Werteker, M., Ruckenbauer, P., Vollman, J., 2000. Stability of quality traits in Austrian-grown winter wheats. Field Crops Research. 66, 257-267.

[20] Johansson, E., Prieto-Linde, M.L., Svensson, G., 2004. Influence of nitrojen application rate and timing on grain protein composition and gluten strengh in Swedish wheat. Plant Nutr. Soil Sci. 167, 345-350.

[21] Koçak, N., Atli, A., Karababa, E.,Tuncer, T., 1992. A research on the quality properties of Hungarian-Yugoslavia bread wheat varieties. Field Crops Central Research. 1, 1-10.

[22] Peleg, Z., Saranga, Y., Yazici, A., Fahima, T., Öztürk, L., Çakmak, I., 2000. Grain zinc, iron and protein concentrations and zinc-efficiency in wild emmer wheat under contrasting irrigation regimes. Plant Soil. 306, 57-67.

[23] Öztürk, L., Yazici, M.A., Yucel, C., Torun, A., Cekic, C., Bagci, A., Ozkan, H., Braun, H.J., Sayers, Z., Çakmak, I., 2006. Concentration and localization of zinc during seed development and germination in wheat. Physiologia Plantarum. 128, 144-152.

[24] Çakmak, I., Erdal, I., 1996. Phytic acid- zinc molar ratios in wheat grains grown in Turkey. Micronutrient and Agriculture. 2, 16-17.

[25] Özcan, H., Taban, S., 2012. Effect of zinc application on yield and grain zinc, phosphorus and phytic acid concentration of some rice genotypes. Soil Water. 1 (1), 7-14.

[26] Shrimpton, R., 1993. Zinc deficiency: is widespread but under recognized. SCN News. 9, 23-27.

[27] Hotz, C., Brown, K.H., 2004. Assessment of the risk of zinc deficiency in populations and options for its control. Food Nutr. Bull. 25, 94-204. 